\title{
Differential Response of Brinjal (Solonum melongena L.) Genotypes for High Temperature Stress on Seed Quality Traits and Peroxidase Activity
}

\author{
K.D. Rajatha ${ }^{1 *}$, B.C. Channakeshava ${ }^{1}$ and K. Bhanuprakash ${ }^{2}$ \\ ${ }^{1}$ Department of Seed Science and Technology, UAS, GKVK Bangalore, Karnataka, India \\ ${ }^{2}$ Seed technology division, IIHR, Hesaraghatta, Bangalore, Karnataka, India \\ *Corresponding author
}

\section{A B S T R A C T}

\begin{tabular}{|l|}
\hline Key w or d s \\
Abiotic stress, High \\
Temperature, Seed \\
Quality, Peroxidase
\end{tabular}

The aim of this study was to investigate the effects of high temperature on seed quality and peroxidase activity. High temperature stress was imposed on four brinjal genotypes at three levels $\left(25^{\circ} \mathrm{C}, 35^{\circ} \mathrm{C}\right.$ and $\left.40{ }^{\circ} \mathrm{C}\right)$. Seeds were allowed to germinate on Petri-plates using two layers of filter paper in hot air oven and seed quality parameters were recorded. As expected, high temperature resulted in decreased seed quality parameters. In germination 100 percent reduction was observed in all the genotypes at severe temperature stress $\left(40{ }^{\circ} \mathrm{C}\right), 53 \%$ was recorded at moderate temperature stress $\left(35^{\circ} \mathrm{C}\right)$, whereas in control $\left(25{ }^{\circ} \mathrm{C}\right) 88.5 \%$ was recorded. Highest mean germination percentage was recorded in Arka Anand (57.33 \%) and lowest was recorded in Arka Shirish (41.25\%). Peroxides activity was high in seedlings exposed to high temperature treatment when compared to control in all the samples. Genotype Arka Anand showed significantly higher activities of peroxidase enzyme in response to high temperature compared to those from the leaves of other genotypes.

\section{Introduction}

Brinjal (Solonum melongena L.) with chromosome number $2 \mathrm{n}=24$ is one of the most important vegetable crop. It is a good source of minerals and vitamins and is rich in total water soluble sugars, free reducing sugars, amide proteins among other nutrients (Anon 2007). The varieties of Solanum melongena $\mathrm{L}$. display a wide range of fruit shapes and colours, ranging from oval or egg-shaped to long club-shaped; and from white, yellow, green through degrees of purple pigmentation to almost black. Warm climate plant like eggplant, grown in the temperate climate zone, are subjected to environmental stress which limits crop productivity, its quality, and postharvest life. In the agriculture context, stress has been defined as a phenomenon that limits crop productivity or destroys the biomass (Grime, 1979).

Abiotic stress is the major threat towards the living world more precisely the plant kingdom whose development and productivity is negatively hampered (Gupta et al., 2013). Clear evidence of increasing stress problems in many parts of the world exists. High temperature stress is a major growth limiting factor for most crop plants. Prolonged or even 
a transitory exposure to high temperature leads to altered metabolic functions. Plant parts including leaves, flower buds and roots are all affected by it (Tsukaguchi et al., 2003). Most conspicuous changes take place in the cellular membranes and enzymes. All enzymes from cytoplasm, mitochondria or chloroplasts are influenced by heat stress. The optimal temperature for eggplant growth and development ranges from 22 to $28{ }^{\circ} \mathrm{C}$. One of the major environmental factors affecting plant growth and productivity is high temperature. Germination and seedling establishment are critical stages in the plant life cycle. In crop production stand establishment determines plant density, uniformity and management options (Cheng and Bradford, 1999).

High quality seed lots may improve crop yield in two ways: first because seedling emergence from the seedbed is rapid and uniform, leading to the production of vigorous plants, and second because percentage seedling emergence is high, so optimum plant population density could be achieved under a wide range of environmental conditions. Field grown plants are often subjected to fluctuating temperature that has a profound effect on the plant metabolism. The primary sensor of physical stress is a cell membrane, because a direct reduction in its liquidity is observed (Chinnusamy et al., 2006). Biochemical and physiological acclimation leads to cell membrane stiffening and reorganization of microfilaments which may be followed by activation of $\mathrm{Ca}_{2}{ }^{+}$channels and an increased cytosolic $\mathrm{Ca}_{2}{ }^{+}$level (Orvar et al., 2000)

Plant responses to environmental stress have been associated with activated forms of oxygen, including hydrogen peroxide $\left(\mathrm{H}_{2} \mathrm{O}_{2}\right)$, singlet oxygen, superoxide, and the hydroxyl radical. Heat stress induces or enhances the active oxygen species-scavenging enzymes like superoxide dismutase, catalase, peroxidase and several antioxidants. Peroxidase oxidizes a vast array of compounds (hydrogen donors) in the presence of $\mathrm{H}_{2} \mathrm{O}_{2}$.

\section{Materials and Methods}

Four brinjal varieties viz., Arka Anand, Arka Shirish, Arka Kusumakar and Brinjal green long were selected for water and high temperature stress studies. Seeds of three varieties were collected from Indian Institute of Horticulture Research, Hesaragatta, Bengalur and Brinjal green long is procured from Sri Chamundeshwari seeds and fertilizers.

\section{High temperature stress for seed quality}

Selected varietal seeds were treated with 0.1 $\% \mathrm{HgCl}_{2}$ for 1 minute followed by thorough washing with distilled water for five times and tested for initial seed quality parameters.

Seeds were subjected to temperature stress by using hot air oven. Sixteen replications of 25 seeds of each variety were allowed to germinate on petri-plates using two layers of filter paper and petriplates were wrapped with parafilim to avoid evaporation. The experiment was laid out in a factorial Completely Randomized Design.

\section{Observations recorded}

\section{Germination (\%)}

The total numbers of seeds germinated at final count (14th day) were counted and percentage of germination was expressed based on the normal seedlings.

\section{Mean germination time (days)}

Mean germination time (MGT) was calculated according to the equation of Ellis and Roberts (1980) and expressed in days. 
The equation is as follows:

$\mathrm{MGT}=\Sigma \mathrm{Dn} / \Sigma \mathrm{n}$

Where,

" $\mathrm{D}$ " is the number of days counted from the beginning of the test and " $n$ " is the number of seeds that germinate on day " $\mathrm{D}$ ".

\section{Mean seedling length $(\mathrm{cm})$}

Ten normal seedlings were selected at random from each replication. The length between the collar region and the tip of primary shoot was measured as shoot length.

The length between collar region and the tip of primary root was measured as root length $(\mathrm{cm})$ and the seedling length was computed by using the formula,

Seedling length $=[$ shoot length $(\mathrm{cm})+$ root length $(\mathrm{cm})]$

\section{Mean seedling dry weight (mg)}

Ten seedlings selected for seedling length measurement were used for recording seedling dry weight. After removing the primary leaf (remnant part), seedlings were dried in hot air oven maintained at $85 \pm 2{ }^{0} \mathrm{C}$ for 24 hours and cooled in desiccators over silica gel. The mean seedling dry weight was recorded and expressed in milligrams per seedling.

\section{Seedling vigour index-I (SVI)}

Seedling vigour index (SVI) was calculated by adopting the method suggested by Abdul-Baki and Anderson (1973) and expressed as whole number. The formula used to estimate the SVI is as follows:

SVI-I=Germination (\%) $\mathrm{x}$ Mean seedling length $(\mathrm{cm})$

\section{Electrical conductivity of seed leachate ( $\mu$ Sm-1)}

Electrical conductivity was measured using the procedure mentioned in ISTA, with slight modifications. Seeds were exposed to $35^{\circ} \mathrm{C}$ and $40^{\circ} \mathrm{C}$ for three days and keeping one as a control. Twenty five seeds were taken randomly in four replications and soaked in $125 \mathrm{ml}$ of distilled water for 18 hours at $25 \pm 1$ ${ }^{0} \mathrm{C}$. After incubation, the seed leachate was decanted and the conductivity was measured by Digital Conductivity Meter (Model-D1 9009) and expressed in $\mu \mathrm{Sm}^{-1}$

\section{Total dehydrogenase activity}

The total dehydrogenase activity was determined by method described by Perl et al., (1978) with slight modifications. Seed coat of these imbibed seeds were carefully removed and then soaked in 0.5 per cent tetrazolium solution at $30 \pm 5{ }^{0} \mathrm{C}$ for a period of 24 hours and were washed thoroughly with distilled water. The red colour (Formazan) was diluted from the stained embryos by soaking in $5 \mathrm{ml}$ of 2-methoxyethanol (methyl cellosolve) for 24 hours in an airtight screw capped vials. The extract was decanted and the colour intensity was measured with the help of spectrophotometer (Model-Systronics UV-VIS spectrophotometer 117) at $480 \mathrm{~nm}$. The dehydrogenase activity was expressed in terms of optical density at $480 \mathrm{~nm}$.

\section{High temperature stress for peroxidase activity}

The effect of high temperature on peroxidase activity was studied by selected genotypes were sown in pro trays containing sterilized coco-pith and raised the seedlings for one month, the healthy seedlings from each varieties were chosen and transferred to plastic cup with soil and FYM mixture (60:40) and left for about 3 days to overcome the 
transplanting shock high temperature treatment was given by subjecting plants to $35^{\circ} \mathrm{C}$ and $40^{\circ} \mathrm{C}$ temperature for creating moderate and severe stress respectively about 3 days in STR, NSP,GKVK, Bangalore.

\section{Native polyacrylamide gel electrophoresis (PAGE) analysis of peroxidase isozymes}

Peroxidase was analyzed for isozymic pattern as described by Glaszman et al., (1988) with slight modification as follows. Seedlings were raised at $25{ }^{\circ} \mathrm{C}$ and one month old plants were used the present experiment. Leaf of the seedling was used for extraction of these isozymes.

\section{Peroxidase extraction}

Fully expanded leaf material of one month old plants was collected from each plant group at each temperature application step. Triplicate samples of leaf tissues were frozen immediately and ground in liquid nitrogen and stored at $80^{\circ} \mathrm{C}$ until used as followed by Gulen and Eris (2004). Peroxidase was analyzed for isozymic pattern as described by Glaszman et al., (1988) with slight modification as follows Plants leaves $(0.5 \mathrm{gm})$ were ground thoroughly in a pestle and mortar with liquid nitrogen and homogenized with $250 \mu \mathrm{l}$ of extraction buffer (0.1M Tris-HCL, pH 7.5) under ice condition. The extract was taken in 2 $\mathrm{ml}$ eppendorf tubes and centrifuged at 10,000 $\mathrm{rpm}$ for 15 minutes at $4^{0} \mathrm{C}$. The supernatant was collected and $10 \mu \mathrm{l}$ of tracking dye (1\% bromophenol blue) was added into each tube. $50 \mu$ of sample extract was used for loading

\section{Electrophoresis}

Eight Percent of Resolving gel and five percent stacking gels was prepared by Dadlain and Varier (1993) with slight modifications. Equal volumes of $50 \mu \mathrm{l}$ of isozyme extract were loaded into the wells of stacking gel using micropipette. A current of $1.5 \mathrm{~mA}$ per well with a voltage of 80 was applied until the tracking dye crossed the stacking gel. Later the current was increased to $2 \mathrm{~mA}$ per well and voltage up to 100 . Electrophoresis was carried out at $4^{0} \mathrm{C}$. The gels were stained for peroxidase by $200 \mathrm{ml}$ of $0.05 \mathrm{M}$ sodium acetate buffer, $\mathrm{pH} 4.5$ for an hour on shaker to bring down the $\mathrm{pH}$ of the resolving gel to 4.5 from 8.8. Then the gel was transferred on to tray containing 3-9 AEC solution and 3-5 ml of hydrogen peroxide (30 \%) was added drop by drop on the gel and agitated slowly for 510 minutes until the reddish bands appear. After staining of gel for peroxidase, the gel was placed on the white light illuminator and the zymogram was prepared by tracing the bands on the transparency sheet placed on the gel.

\section{Statistical analysis}

The statistical analysis and the interpretation of the experimental data was done by using Fisher method of Analysis of Variance techniques as outlined by Gomez and Gomez (1984) and critical difference were calculated at five per cent level of significance where "F" was significant for seed quality parameters. The total distance travelled by the tracking dye and the distance of each band from the point of loading was measured. The Rm value was calculated, other observations like, total number of bands in each lane (genotype), the relative intensities of peroxidase bands (1light intensity, 2- medium intensity, 3- high intensity and 4- very high intensity) and presence or absence of bands( 1 for present and 0 for absent) at each $\mathrm{Rm}$ value was recorded and scored.

\section{Results and Discussion}

During the plants entire life cycle, plants are exposed to various environmental stresses. Two major categories can be distinguished: 
abiotic stress and biotic stress. Both types of stress negatively affect the seed yield, quality and survival of plants (Shaik and Ramakrishna, 2014). Abiotic stress reduces seed yield and quality, so that novel crop genotypes adapted to environmental stress need to be developed (Wu et al., 2014; Dolferus, 2014). Plants have developed a range of morphological, physiological and biochemical mechanisms that enable them to avoid and/or tolerate stress factors and survive (Potters et al., 2006). Therefore an attempt was made to understand seed quality changes as well as biochemical response of plants to abiotic stresses in different genotypes.

It was noticed that as the temperature increased from $25^{0} \mathrm{C}$ to $40^{\circ} \mathrm{C}$, stress affected the seed germination percentage in brinjal. Highest seed germination recorded was 88.5 $\%$ at $25^{\circ} \mathrm{C}, 53.3 \%$ at $35^{\circ} \mathrm{C}$ and none of the genotype was able to germinate at $40^{\circ} \mathrm{C}$. Among the genotypes studied highest percent germination was recorded in Arka Anand $(72 \%)$ and lowest was recorded in Arka Shirish $(41 \%)$ at $35^{\circ} \mathrm{C}$ as represented in Figure 1. Mean germination time differed significantly among the genotypes, highest was recorded in Brinjal green long (7.63 days) and lowest in Arka Anand (7.30 days). The sum of shoot length and root length is total seedling length (MSL), the highest MSL was recorded in Arka Anand $(6.94 \mathrm{~cm})$, followed by Arka Kusumakar $(6.25 \mathrm{~cm})$, least was recorded in Arka Shirish $(5.57 \mathrm{~cm})$ and it was found to be on par with Brinjal green long $(5.75 \mathrm{~cm})$. High temperature stress affected MSL severely highest was recorded in control $(10.47 \mathrm{~cm})$, followed by at $35^{0} \mathrm{C}(7.96 \mathrm{~cm})$. Seedling vigour index $\mathrm{I}$ is the product of total seedling length and germination percentage, the seedling vigour index differed significantly among the genotypes, highest seedling vigour index was recorded in Arka Anand (611.2) and lowest was recorded in Brinjal green long (289.43).
The effect of high temperature on Germination (\%), Mean Germination Time (days), Mean Seedling Length $(\mathrm{cm})$, Seedling dry weight $(\mathrm{g})$ and SVI-I represented in Table 1 and 2 . The results showed drastic reduction physiological parameters tested when compared to control with moderate high temperature stress and 100 $\%$ drop in severe high temperature stress.

Total dehydrogenase activity was studied under different high temperature stress conditions results showed that total dehydrogenase activity differed among the brinjal genotypes. Mean value of Arka Anand (2.72) showed the highest total dehydrogenase activity which was on par with Arka Kusumakar (2.45) followed by Brinjal green long (1.97), least was noticed in Arka Shirish (1.90). The membrane damage was assessed indirectly by conductometric measurements of ion leakage from seeds. The percentage of electrolyte leakage from the seeds of the moderate and severe high temperature stress was high when compared to that of control as shown in Figure 1. Arka Anand showed lesser membrane damage both at $35^{\circ} \mathrm{C}$ and $40^{\circ} \mathrm{C}$ temperatures compared to other genotypes.

To acquire a comprehensive knowledge of the activated processes during high temperature stress, peroxidase isozyme profiling was carried out for the high temperature subjected seeds. After electrophoresis, the sample lane was divided into 18 bands based on its decreasing order of molecular weight. The presence or absence of specific band or group of bands as well as band intensity was taken as the criteria to characterize the peroxidase profile extracted stress subjected seeds of brinjal. The stress treatments from 1 to 12 were scored as low, medium, high intensity and very high intensity with $\mathrm{Rm}$ value ranged from 0.097 to 0.814. All the stressed treatments showed significant differences either by the presence or absence of bands and as well as their intensity. 


\section{High temperature stress for seed quality}

\begin{tabular}{|l|l|c|l|}
\hline & Varieties & & Stress level \\
\hline $\mathbf{V}_{\mathbf{1}}$ & Arka Anand & $\mathrm{T}_{0}$ & Control $\left(25^{\circ} \mathrm{C}\right)$ \\
\hline $\mathbf{V}_{\mathbf{2}}$ & Arka Shirish & $\mathrm{T}_{1}$ & Moderate high temperature stress $\left(35^{\circ} \mathrm{C}\right)$ \\
\hline $\mathbf{V}_{\mathbf{3}}$ & Brinjal green long & $\mathrm{T}_{2}$ & Severe high temperature stress $\left(40^{\circ} \mathrm{C}\right)$ \\
\hline $\mathbf{V}_{4}$ & Arka Kusumakar & &
\end{tabular}

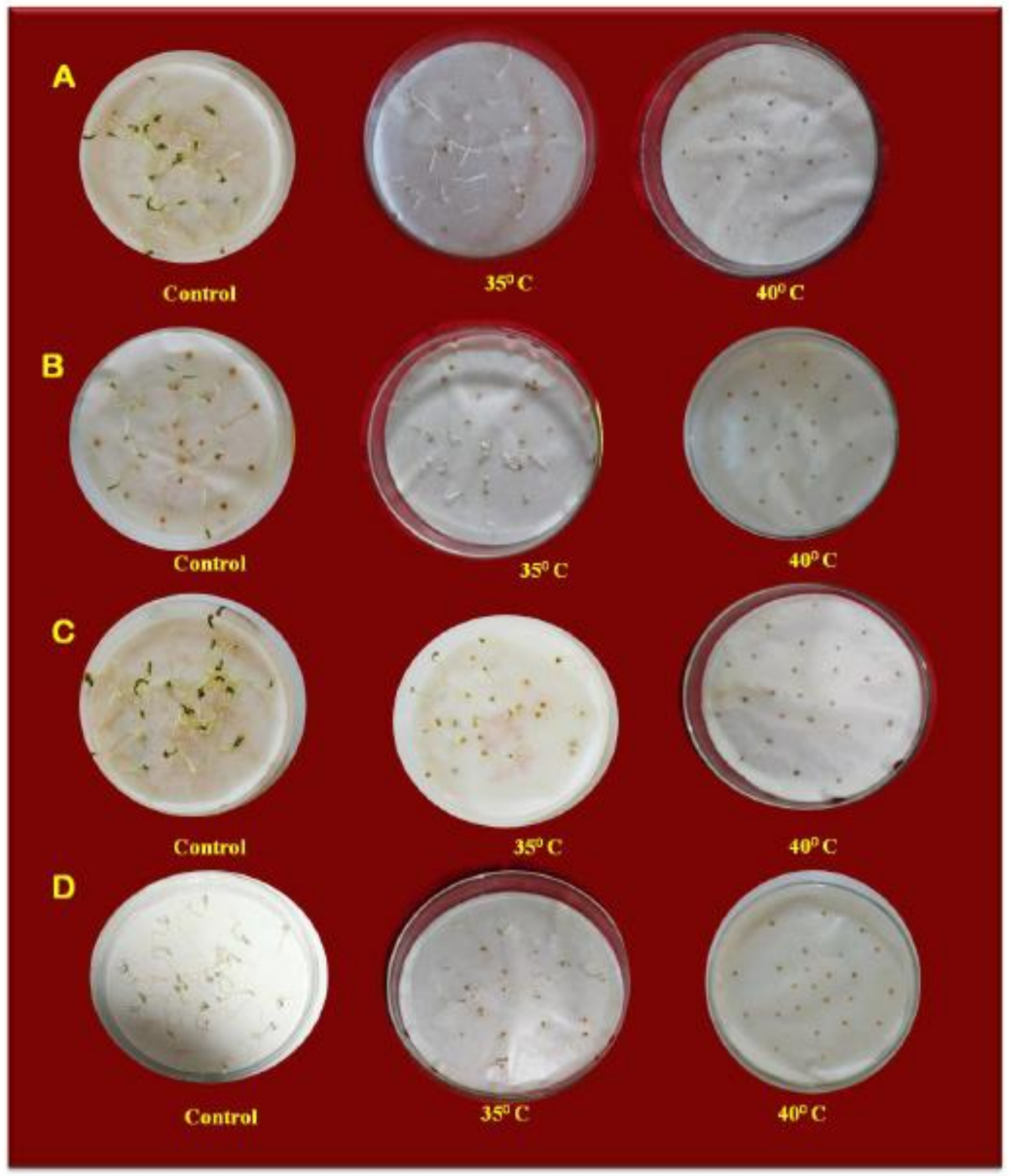

Figure 1 :Effect of high temperature stress on germination of Brinjal A-Arka Anand B-Arka Shirish- C- Green Long D-Arka Kusumakar 


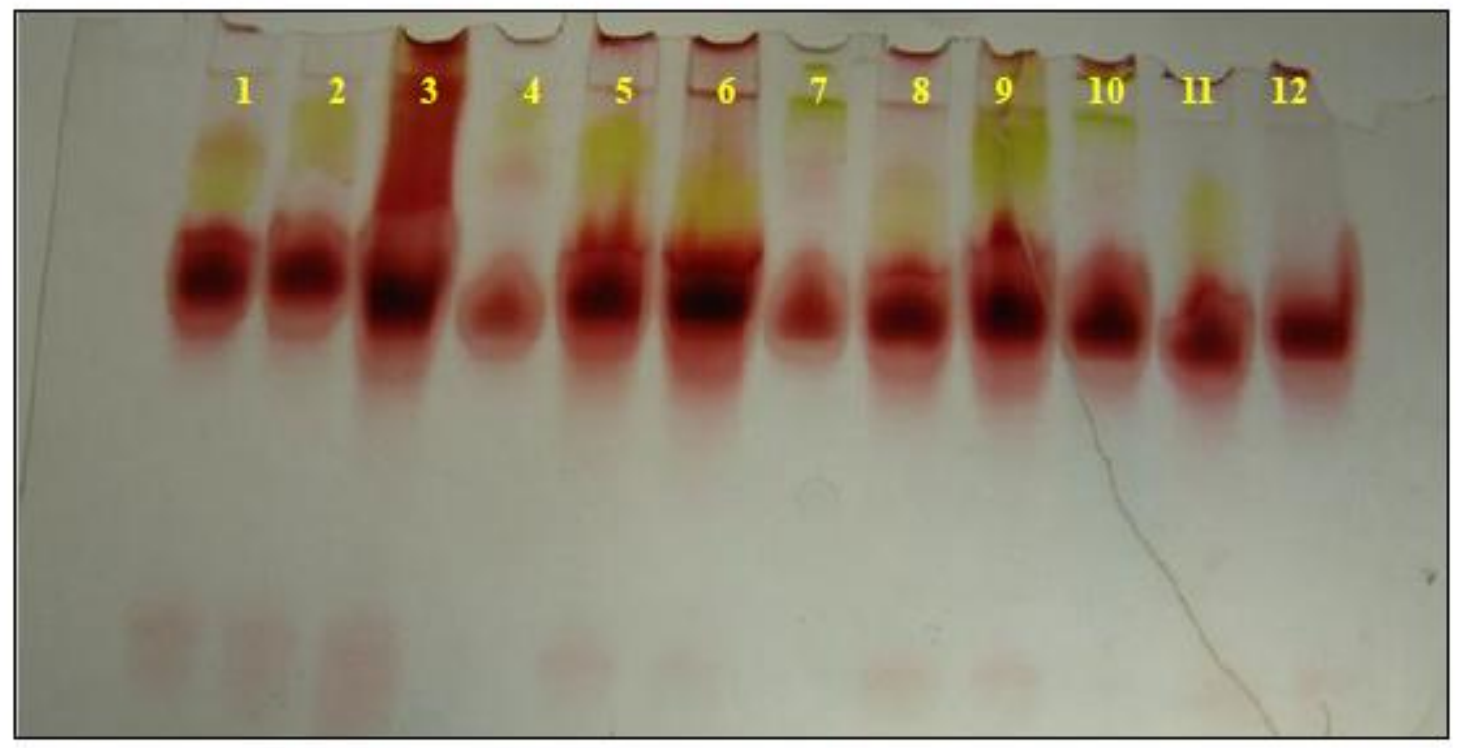

Plate 1. Effect of high temperature stress on peroxidase profile in brinjal genotypes

\begin{tabular}{|l|l|l|l|l|l|}
\hline 1: & $\mathrm{V}_{1} \mathrm{~T}_{0}$ & 5: & $\mathrm{V}_{4} \mathrm{~T}_{1}$ & 9: & $\mathrm{V}_{2} \mathrm{~T}_{2}$ \\
\hline 2: & $\mathrm{V}_{1} \mathrm{~T}_{1}$ & 6: & $\mathrm{V}_{4} \mathrm{~T}_{2}$ & 10: & $\mathrm{V}_{3} \mathrm{~T}_{0}$ \\
\hline 3: & $\mathrm{V}_{1} \mathrm{~T}_{2}$ & 7: & $\mathrm{V}_{2} \mathrm{~T}_{0}$ & 11: & $\mathrm{V}_{3} \mathrm{~T}_{1}$ \\
\hline 4: & $\mathrm{V}_{4} \mathrm{~T}_{0}$ & $\mathbf{8 :}$ & $\mathrm{V}_{2} \mathrm{~T}_{1}$ & $\mathbf{1 2 :}$ & $\mathrm{V}_{3} \mathrm{~T}_{2}$ \\
\hline
\end{tabular}

$\begin{array}{llllllllllll}\mathrm{V}_{1} \mathrm{~T}_{0} & \mathrm{~V}_{1} \mathrm{~T}_{1} & \mathrm{~V}_{1} \mathrm{~T}_{2} & \mathrm{~V}_{4} \mathrm{~T}_{0} & \mathrm{~V}_{4} \mathrm{~T}_{1} & \mathrm{~V}_{4} \mathrm{~T}_{2} & \mathrm{~V}_{2} \mathrm{~T}_{0} & \mathrm{~V}_{2} \mathrm{~T}_{1} & \mathrm{~V}_{2} \mathrm{~T}_{2} & \mathrm{~V}_{3} \mathrm{~T}_{0} & \mathrm{~V}_{3} \mathrm{~T}_{1} & \mathrm{~V}_{3} \mathrm{~T}_{2}\end{array}$

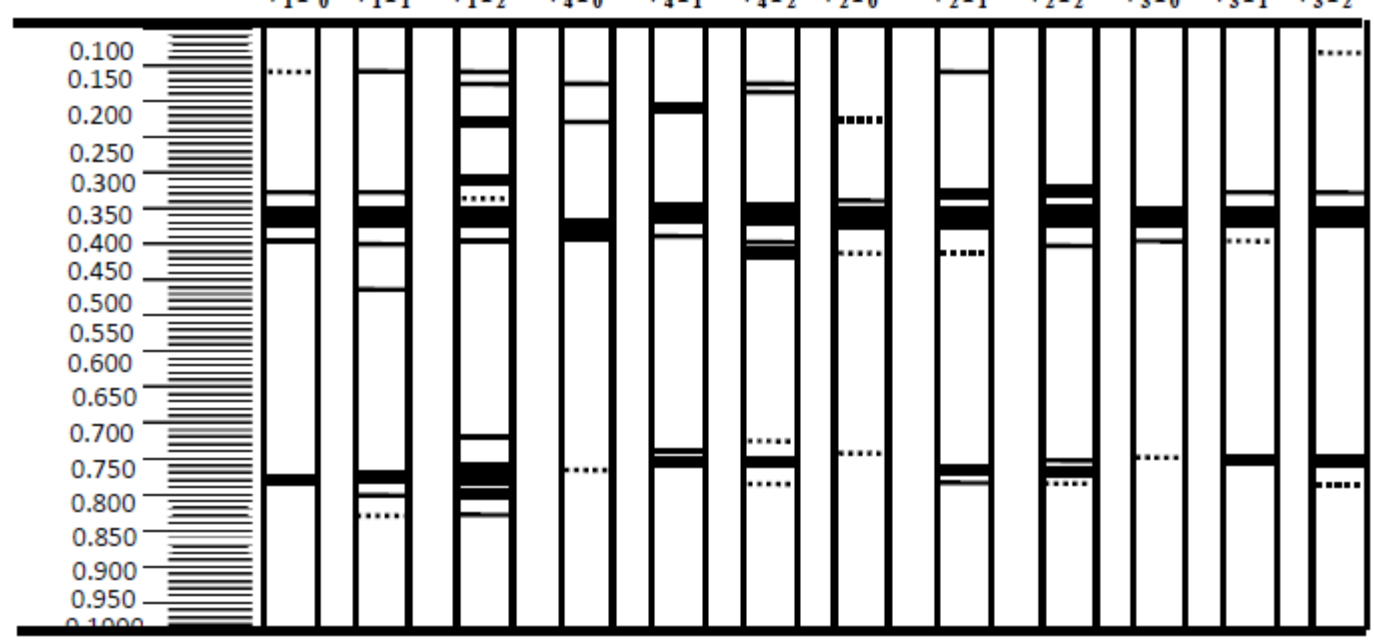

Plate 2. Zymogram of peroxidase profile due to high temperature stress in brinjal genotypes

\begin{tabular}{|l|l|l|l|l|l|}
\hline & & & ++ & $:$ & Low \\
\hline++++ & $:$ & High & + & $:$ & Very Low \\
\hline+++ & $:$ & Medium & Absent & $:$ & No band \\
\hline
\end{tabular}


Table.1 Effect of high temperature stress on seedling traits such as germination (\%) and mean germination time (days)

\begin{tabular}{|c|c|c|c|c|c|c|c|c|}
\hline \multirow[t]{2}{*}{ Treatments } & \multicolumn{4}{|c|}{ Germination (\%) } & \multicolumn{4}{|c|}{ Mean Germination Time (days) } \\
\hline & $\mathbf{T}_{\mathbf{0}}$ & $\mathbf{T}_{1}$ & $\mathbf{T}_{2}$ & Mean & $\mathbf{T}_{\mathbf{0}}$ & $\mathbf{T}_{1}$ & $\mathbf{T}_{2}$ & Mean \\
\hline$V_{1}$ & 100.0 & 72.0 & 0.0 & $\mathbf{5 7 . 3 3}$ & 10.24 & 11.66 & 0.00 & 7.30 \\
\hline $\mathrm{V}_{2}$ & 82.5 & 41.3 & 0.0 & 41.25 & 10.87 & 11.90 & 0.00 & 7.59 \\
\hline $\mathbf{V}_{3}$ & 81.0 & 44.0 & 0.0 & 41.67 & 10.66 & 11.89 & 0.00 & 7.63 \\
\hline $\mathbf{V}_{4}$ & 88.5 & 56.0 & 0.0 & 48.17 & 10.59 & 11.82 & 0.00 & 7.47 \\
\hline \multirow[t]{5}{*}{ Mean } & 88 & 53.3 & 0.0 & & 10.59 & 11.82 & 0.00 & \\
\hline & & S.Em \pm & $\mathrm{CD}(\mathrm{P}=0.01)$ & CV (\%) & & S.Em \pm & $\mathrm{CD}(\mathrm{P}=0.01)$ & CV $(\%)$ \\
\hline & $\mathbf{V}$ & 0.362 & 1.394 & 2.665 & V & 0.049 & 0.190 & 2.293 \\
\hline & $\mathbf{T}$ & 0.314 & 1.207 & & $\mathbf{T}$ & 0.043 & 0.165 & \\
\hline & VT & 0.628 & 2.414 & & VT & 0.086 & 0.329 & \\
\hline
\end{tabular}

Table.2 Effect of high temperature stress on mean seedling length $(\mathrm{cm})$, seedling dry weight $(\mathrm{mg})$ and seedling vigour index-I

\begin{tabular}{|c|c|c|c|c|c|c|c|c|c|c|c|c|}
\hline \multirow{2}{*}{ Treatments } & \multicolumn{4}{|c|}{ Mean seedling length $(\mathrm{cm})$} & \multicolumn{4}{|c|}{ Seedling dry weight (mg) } & \multicolumn{4}{|c|}{ Seedling vigour index-I } \\
\hline & $\mathbf{T}_{\mathbf{0}}$ & $\mathbf{T}_{\mathbf{0}}$ & $\mathbf{T}_{1}$ & $\mathbf{T}_{\mathbf{0}}$ & $\mathbf{T}_{1}$ & $\mathbf{T}_{\mathbf{0}}$ & $\mathbf{T}_{1}$ & $\mathbf{T}_{\mathbf{0}}$ & $\mathbf{T}_{1}$ & $\mathbf{T}_{1}$ & $\mathbf{T}_{2}$ & Mean \\
\hline$V_{1}$ & 11.57 & 10.40 & 5.80 & 10.40 & 5.80 & 10.40 & 5.80 & 10.40 & 5.80 & 9.26 & 0.00 & 6.94 \\
\hline $\mathbf{V}_{2}$ & 10.11 & 8.05 & 4.28 & 8.05 & 4.28 & 8.05 & 4.28 & 8.05 & 4.28 & 6.78 & 0.00 & 5.63 \\
\hline$V_{3}$ & 9.82 & 7.88 & 4.73 & 7.88 & 4.73 & 7.88 & 4.73 & 7.88 & 4.73 & 7.43 & 0.00 & 5.75 \\
\hline $\mathbf{V}_{4}$ & 10.39 & 9.40 & 5.15 & 9.40 & 5.15 & 9.40 & 5.15 & 9.40 & 5.15 & 8.36 & 0.00 & 6.25 \\
\hline \multirow[t]{5}{*}{ Mean } & 10.47 & 8.74 & 4.99 & 8.74 & 4.99 & 8.74 & 4.99 & 8.74 & 4.99 & 7.96 & 0.00 & \\
\hline & & & S.Em \pm & & S.Em \pm & & S.Em \pm & & S.Em \pm & S.Em \pm & $\mathrm{CD}(\mathrm{P}=0.01)$ & CV (\%) \\
\hline & $\mathbf{V}$ & $\mathbf{V}$ & 0.050 & $\mathbf{V}$ & 0.050 & $\mathbf{V}$ & 0.050 & $\mathbf{V}$ & 0.050 & 0.037 & 0.144 & 2.123 \\
\hline & $\mathbf{T}$ & $\mathbf{T}$ & 0.044 & $\mathbf{T}$ & 0.044 & $\mathbf{T}$ & 0.044 & $\mathbf{T}$ & 0.044 & 0.032 & 0.124 & \\
\hline & VT & VT & 0.087 & VT & 0.087 & VT & 0.087 & VT & 0.087 & 0.065 & 0.220 & \\
\hline
\end{tabular}


In general, the peroxidase bands observed in the severe temperature stress $\left(40^{\circ} \mathrm{C}\right)$ samples were darker than those in moderate stress $\left(35^{\circ} \mathrm{C}\right)$ samples whereas, it was faint in control (unstressed) sample in all the samples (Plate 1).

The present study results showed that temperature played an important role in germination as seen in the decrease in the germination percentage with increase in the temperature regimes. Higher germination (57 $\%$ ) was recorded in $\mathrm{V}_{1}$ and lower was in $\mathrm{V}_{3}$. Mean germination time was observed maximum in $V_{3}$ (7.63 days) and minimum was recorded in $\mathrm{V}_{1}$ (7.30 days).The results of the present study evidenced that, high temperature prolongs the mean germination time; reason might be reduction in the rate of metabolic reactions could occur at high temperature, affecting the essential processes that initiate germination. At very high temperature stress, the rate of germination was strictly prohibited and caused cell death and embryos for which seedling establishment rate was also reduced. Higher seedling dry weight $(5.40 \mathrm{mg})$ was recorded in $\mathrm{V}_{1}$ and lower was recorded in $\mathrm{V}_{2}(4.11 \mathrm{mg})$. The variation is might be due to, high-temperature likely to inhibit the ability of the plant to supply the seeds with the assimilates necessary to synthesize the storage compounds required during the germination process (Dornbos and McDonald 1986), and the seeds suffer physiological damage (McDonald and Nelson 1986; Coolbear 1995; Powell 2006), results in low mobilization efficiency and poor development of root and shoot in terms of robustness. Thus, there was a reduction in seedling dry weight.

Cell membrane stability has been widely used to express stress tolerance, and higher membrane stability could be correlated with abiotic stress tolerance. Seed leachate conductivity (which is an indicator of cell membrane integrity - Powell, 2006) was increased only after exposure of the developing seeds to the high temperature. Higher electrical conductivity $\left(326.75 \mu \mathrm{Sm}^{-1}\right)$ was recorded in V2 and lower was recorded in $\mathrm{V}_{1}\left(222.58 \mu \mathrm{Sm}^{-1}\right)$.
The reason might be high temperature results in membrane disorganization which intern results in increase in leakage of electrolytes from cytoplasm (McDonald, 1999). Thus there was increase in electrical conductivity. Elevated temperatures were deleterious to enzyme activity. The present study results indicate decrease in total dehydrogenase activity. Higher dehydrogenase enzyme activity (2.72) was recorded in $\mathrm{V}_{1}$ and lower in $\mathrm{V}_{2}$ (1.90). The temperature stress leads to reduced enzyme activity, because they undergo conformational changes results in malfunctioning.

\section{Electrophoretic analyses of peroxidase (POX) isozyme}

Under temperature stress conditions, peroxidase expressed novel banding pattern with $\mathrm{Rm}$ values of 0.097 to 0.814 (Plate 1). The banding profile of peroxidase isozyme revealed polymorphism among temperature stress treatments with the presence or absence of bands. However, intensity was varied among the genotypes and high temperature levels. Irrespective of genotypes, at high temperature stress levels $\left(40^{\circ} \mathrm{C}\right)$; all the varieties were exhibiting the bands, but the noticing point here was the rate of expression in terms of number and intensity of bands. The results were in agreement with Moaed et al., (2006) who also observed temperature stress adversely affecting plant processes that lead to loss of cellular homeostasis accompanied by the formation of reactive oxygen species (ROS), which causes oxidative damage to membrane, lipids, proteins and nucleic acids (Srivalli et al., 2003).

Plants are exposed multiple abiotic stress and high temperature stress is one of the kind. The results obtained from the above studies made evident that there was negative relationship between high temperature stress with seed quality attributes and this relation varies with the genotypes. Hence suitable genotypes need to be selected to tolerate these conditions. The study could be helpful to identify and select the varieties which are high temperature tolerant. 
The results obtained clearly indicated that over expression of some of the key enzymes viz peroxidase will help to cope up with the ill effects of stress in response to abiotic stress effects particularly high temperature stress. The coordinate function of antioxidant enzymes such as SOD, POX, catalase and GR helps in processing of ROS and regeneration of redox ascorbate and glutathione metabolites.

The oxidative damage to cellular components is limited under normal growing conditions due to efficient processing of ROS through a wellcoordinated and rapidly responsive antioxidant system consisting of several enzymes particularly POX and redox metabolites. It is clear from the data that there was a significant increase in the POX enzymes activity in response to high temperature stress.

\section{Acknowledgement}

I am grateful to all the scientists who supported to conduct my research work successfully and This research was partially supported by molecular lab, Seed Technology Research Unit, University of Agricultural Sciences, Bangalore and Indian Institute of Horticultural Research, Bangalore I thank for their support and for the seed materials provided by them.

\section{References}

Abdul-Baki A.A. and Anderson J. D. 1973. Vigor determination in soybean seed by multiple criteria. Crop Science, 13, 630633

Annonymus. 2007. Food and agriculture organization statistics.

Cheng, Z.Y. and Bradford, K.J. 1999. Hydrothermal time analysis of tomato seed germination responses to priming treatments. Journal of Experimental Botany, 50, 89-99.

Chinnusamy, V., Zhu, J., and Zhu, J.-K. 2005. Gene regulation during cold acclimation in plants. Physiologia Plantarum, 126, $52-61$.
Coolbear, P. 1995. Mechanisms of seed deterioration. In seed quality: basic mechanisms and agricultural implications (Ed. A. S. Basra). New York: Food Products Press, 223-277.

Dadlani M. and Varier A. 1993. Electrophoresis for variety identification. Tech. Bull. Division of Seed Science and Technology, Indian Agricultural Research Institute, New Delhi.

Dolferus, R. 2014. To grow or not to grow: A stressful decision for plants. Plant Science, 229, 247-261.

Dornbos, D. L. and Mc Donald, M. B. 1986. Mass and composition of developing soybean seeds at five reproductive growth stages. Crop Science, 26, 624-630.

Ellis, R. H. and Roberts, E. H. 1980. Towards rational basis for testing seed viability. Hebbelethwaite, P.D (ed.), Seed Production, Butterworths, London, 605635.

Glaszmann, I.C., Los Reyes B.G. D. and Khush, G.S. 1988 Electrophoretic variation of isozymes in plumulzs of rice (Oryza sativa L.) a key to the identification of 76 alleles at 24 loci, The International Rice Research Institute, 1-15.

Gomez, K, A. and GOMEZ A. A. 1984. Statistical Procedures in Agricultural Research. 2nd edition Wiley New York Chichester, 680.

Grime, J. P. 1979. Plant strategies and vegetation process. Print house Chichester, New York: John Wiley. 22-28

Gulen, H. and Eris, A. 2004. Effect of heat stress on peroxidase activity and protein content in strawberry plants. Plant Science, 166: 739-744

Gupta. B, Sengupt A.A., Saha J. and Gupta, K. 2013. Plant abiotic stress: 'Omics' approach. Plant Biochemistry and Physiology, 36(7) 1-3.

Gutterman, Y. 2002. Survival strategies of annual desert plants: adaptations of desert organisms. Springer, Berlin. http://dx.doi. org/10.1007/978-3-642-55974-7. 
Mcdonald, M. B. 1999 Seed deterioration: physiology, repair and assessment. Seed Science and Technology, 27, 177-237

Mcdonald, M. B. AND Nelson, C. J. 1986. Physiology of seed deterioration. Special publication No. 11, Madison, WI, USA: Crop Science Society of America, 24-30.

Moaed, A., Deshmukh, P. S. and Sairam, R. K. 2006. High temperature stress tolerance in wheat genotypes: role of antioxidant defence enzymes. Acta Agronomica Hungarica, 57, 1-14.

Orvar, B.L., Sangwan, V., Omann, F. and Dhindsa, R.S. 2000. Early steps in cold sensing by plant cells: the role of actin cytoskeleton and membrane fluidity, Plant Journal, 23, 785-794

Perl, M., Luria, I. and Gelmond, H. 1978. Biochemical changes in sorghum seeds affected by accelerated ageing. Journal of Experimental Botany, 29, 497-501.

Potters, G., Jansen, M. A. K., Guisez, Y. and Pasternak, T. 2006. Stress drives plant cells to take the road towards embryogenesis. In Floriculture, Ornamental and Plant Biotechnology, Advances and Topical Issues; Teixeira da Silva, J. A., Ed.; Global Science Books Ltd.: London, UK, 2, 289-294.

Powell, A. A. 2006. Seed vigour and its assessment. In Handbook of Seed Science and Technology (Ed. A. S. Basra). Food Products Press, 603-648.
Premachandra, G.S., Saneoka, H., Fujita, K. and Ogata, S. 1992. Leaf water relations, osmotic adjustment, cell membrane stability, epi-cuticular wax load and growth as affected by increasing water deficits in Sorghum, Journal of Experimental Botany. 43, 1569-1576.

Shaik, R. and Ramakrishna, W. 2014. Machine learning approaches distinguish multiple stress conditions using stress-responsive genes and identify candidate genes for broad resistance in rice. Plant Physiology, $164,481-495$.

Srivalli, B., Vishanathan, C. and Renu, K. C. 2003. Antioxidant defense in response to abiotic stresses in plants. Journal of Plant Biology, 30, 121-139.

Tsukaguchi, T., Kawamitsu, Y., Takeda, H., Suzuki, K. AND EGAWA, Y., 2003, Water status of flower buds and leaves as affected by high temperature in heattolerant and heat-sensitive cultivars of snap bean (Phaseolus vulgarisL.). Plant Production Science, 6, 24-27.

Wu, Q., Shu, P. C., Cai, T., Fan, X. W. and Li, Y. Z. 2014. Existence of abiotic stressresponsive genes within the regions of QTLs controlling maize grain yield: One of the root causes for unstability of the QTLs. South African Journal of Botany, 93, 231-241.

\section{How to cite this article:}

Rajatha, K.D., B.C. Channakeshava and Bhanuprakash, K. 2018. Differential Response of Brinjal (Solonum melongena L.) Genotypes for High Temperature Stress on Seed Quality Traits and Peroxidase Activity. Int.J.Curr.Microbiol.App.Sci. 7(05): 3131-3141. doi: https://doi.org/10.20546/ijcmas.2018.705.366 